\title{
Studies on the Mode of Action of Excess of Vitamin A
}

\section{EFFECT OF EXCESS OF VITAMIN A ON THE METABOLISM AND COMPOSITION OF EMBRYONIC CHICK-LIMB CARTILAGE GROWN IN ORGAN CULTURE}

\author{
BY J. T. DINGLE, J. A. LUCY AND HONOR B. FELL* \\ Strangeways Research Laboratory, Cambridge
}

(Received 8 September 1960)

Fell \& Mellanby (1952) showed that in organ cultures the addition to the medium of excess of vitamin A (10-15 i.u./ml.) severely affects cartilaginous limb-bone rudiments from 6-7-day chick embryos. During 7-10 days' cultivation, the vitamin A-treated rudiments cerse to grow, begin to shrink and become soft and gelatinous; the matrix no longer stains metachromatically with toluidine blue and the intercellular partitions become narrow and eventually disappear. These effects on the matrix are accompanied by cytological changes; the cartilage cells become smaller and less vacuolated and lose most of their glycogen (Fell \& Thomas, 1960). They remain viable, however, and continue to multiply by mitosis. In experiments on foetal-mouse cartilage, it was shown that if the cells are killed by heating to $45^{\circ}$ for 15 min., vitamin $A$ has no effect on the explants (Fell \& Mellanby, 1952).

In radioautographic experiments with labelled inorganic sulphate $\left({ }^{35} \mathrm{SO}_{4}\right)$, Fell, Mellanby \& Pelc (1956) found that in the presence of the vitamin the explants first cease to take up sulphate and then lose that already incorporated; in the matrix the loss of ${ }^{35} \mathrm{SO}_{4}$ is accompanied by the disappearance of metachromasia. They concluded that vitamin A first inhibits the synthesis of new chondroitin sulphate and then causes the dissolution of that already formed. That these effects of vitamin $\mathbf{A}$ on cartilage matrix and cells are not peculiar to organ cultures has recently been demonstrated by Thomas, McCluskey, Potter \& Weissmann (1960), who observed similar changes in the cartilage of young rabbits dosed with excess of vitamin A.

The object of the present investigation was to find what biochemical changes are associated with the morphological effects of excess of vitamin A on limb-bone rudiments in culture.

\section{MATERIALS AND METHODS}

Organ culture. The humeri, femora and tibiae of 7-day chick embryos were grown by the watch-glass method described by Fell \& Mellanby (1952). Each watch glass

\footnotetext{
* Foulerton Research Fellow, Royal Society.
}

contained a mixture of 15 drops of cock's blood plasma and 5 drops of embryo extract. The extract, which was made from 13- to 14-day chick embryos, was prepared by mixing equal parts of embryo pulp and Tyrode solution supplemented with $1 \%(w / v)$ of glucose; the mixture was centrifuged for 5 min.

Synthetic vitamin A alcohol (Roche Products, London) was dissolved in ethanol and added to the plasma; the same quantity $(0.2 \%)$ of ethanol without the vitamin was added to the control plasma. The final medium contained 10 i.u. of vitamin $A / \mathrm{ml}$. The rudiments from one side of each embryo were grown in vitamin A medium, and those from the opposite side in control medium. They were transplanted to fresh clots at 2-day intervals and were harvested for biochemical study after 6 days' cultivation.

Analyses. After incubation the bones were washed in iso-osmotic $0.9 \% \mathrm{NaCl}$ soln., blotted dry on filter paper and weighed. The dry weights were obtained from the lipid-free material after extraction with ether. Ribonucleic acid (RNA) was estimated by the method of J. Biggers, $K$. Lawson, J. A. Lucy \& M. Webb (unpublished), and deoxyribonucleicacid (DNA) by the method of Burton (1956). Results are expressed as $\mu \mathrm{g}$. of nucleic acid phosphorus.

Bone rudiments and samples for hexosamine analysis were hydrolysed in $5 \mathrm{~N}-\mathrm{HCl}$ for $4 \mathrm{hr}$. at $100^{\circ}$. This procedure was always used in all analyses; no attempt was made to determine the hydrolysis conditions for optimum yields of hexosamine since the experiments were comparative and absolute quantities were not required. After hydrolysis, the samples were dried over phosphorus pentoxide in vacuo, and subsequently redissolved in $0.5 \mathrm{~N}-\mathrm{HCl}$ before analysis for total hexosamine content. Each sample was transferred to a $23 \mathrm{~cm}$. column of Amberlite ion-exchange resin, CG-120 (II), washed in with $10 \mathrm{ml}$. of water and then eluted with $2 \mathrm{~N}-\mathrm{HCl}$ at room temperature to remove non-hexosamine components that interfere in the Elson-Morgan reaction (Boas, 1953). In experiments in which glucosamine and galactosamine were determined separately, the hydrolysed sample was redissolved in $0 \cdot 3 \mathrm{~N}-\mathrm{HCl}$ and placed on a $60 \mathrm{~cm}$. column of the same resin; elution was with $0.3 \mathrm{~N}-\mathrm{HCl}$ at room temperature (Gardell, 1953). The eluted hexosamines were estimated by the procedure of Rondle \& Morgan (1955); four different concentrations of a standard solution of glucosamine hydrochloride were included with each batch of samples.

Metabolism. The oxygen uptake of the bones was measured by conventional Warburg techniques. Twelve bone rudiments were put into each flask. The vitamintreated bones were each approx. 4-5 mm. in length and weighed about $2 \mathrm{mg}$. The control bones were about 6-7 mm. in length and weighed about $4 \mathrm{mg}$. The suspending medium

Bioch. 1961, 79 
was Krebs-Ringer phosphate (Umbreit, Burris \& Stauffer, 1957) containing $1.8 \mathrm{mg}$. of glucose $/ \mathrm{ml}$. and $10 \%$ of horse serum. To prevent the bicarbonate in the serum from altering the $\mathrm{pH}$ of the medium, the horse serum was pretreated by the method of Friend \& Hastings (1940). The gas phase was air, and $20 \%$ sodium hydroxide was included in the centre well. All flasks had an equilibration period of $10 \mathrm{~min}$. at $37^{\circ}$, after which incubation was continued for 90 min.; over this period the rate of oxygen uptake was linear. Agitation rate was 120 strokes/min. At the end of the incubation period $1 \mathrm{ml}$. of suspending fluid was removed, made up to $7 \mathrm{ml}$. and $1.5 \mathrm{ml}$. of $5 \%(w / v)$ $\mathrm{ZnSO}_{4}, 6 \mathrm{H}_{2} \mathrm{O}$ and $1.5 \mathrm{ml}$. of approx. $0.3 \mathrm{~N}-\mathrm{Ba}(\mathrm{OH})_{2}$ were added. Lactic acid was estimated by the method of Barker \& Summerson (1941) and glucose by the method of Nelson (1944).

Clot lysis. At the end of the culture period the bone rudiments were removed from their supporting clot and washed in salt solution. The washings were returned to the culture medium and an equal volume of $10 \%$ trichloroacetic acid was added. The precipitate was spun off and washed twice with $5 \%$ trichloroacetic acid. The acidinsoluble material was dissolved in $5 \mathrm{~N}-\mathrm{KOH}$ and samples of this and of the acid-soluble material were estimated for nitrogen content by the micro-Kjeldahl method (Hawk, Oser \& Summerson, 1952). The amount of clot digestion is expressed as the percentage of acid-soluble nitrogen.

\section{RESULTS}

Effect of vitamin $A$ on the composition of bone rudiments. Cultivation of the bone rudiments in the presence of added vitamin $A$, under the condi- tions reported here, severely decreased the metachromatic staining reaction of the matrix with toluidene blue. This reaction is believed to be specific for sulphate esters of high-molecularweight substances (Kent \& Whitehouse, 1955) and it is probable therefore that the lack of metachromatic staining is related to the $50 \%$ loss of amino sugars (Table 1). There was some alteration in the ratio of glucosamine/galactosamine, since the vitamin A-treated explants lost slightly more galactosamine. The decrease in total hexosamine content of the vitamin A-treated rudiments was accompanied by a quantitatively similar decrease in the wet and dry weights; that these changes were not due simply to the presence of fewer cells in the vitamin A-treated explants is shown by the fact that the ratio dry weight/DNA, which gives an approximate measure of the ratio of total mass to cell number, was much lower in the vitamin Atreated rudiments.

Though there is little cellular degeneration in vitamin A-treated explants at the stage used in this work, the vitamin affects the ratio DNA/RNA (Table 2); DNA showed a drop of $20 \%$ as compared with the controls, whereas RNA was lowered by over $60 \%$.

Metabolism. The presentation of metabolic results is made difficult by the changes in composition of the rudiments. The severe effect of vitamin $\mathbf{A}$ on both the wet and dry weights pre-

\section{Table 1. Weight and amino sugar composition of cartilaginous limb-bone rudiments grown in culture}

The wet-wt. and dry-wt. results are the means of four experiments; analyses were made of material from 12 rudiments. The material for the amino sugar analyses was obtained from 18 rudiments.

\begin{tabular}{|c|c|c|c|c|c|c|}
\hline & $\begin{array}{l}\text { Wet wt. } \\
\text { (mg./bone) }\end{array}$ & $\underset{\text { (mg./bone) }}{\text { Dry wt. }}$ & $\begin{array}{l}\text { Dry wt./ } \\
\text { DNA P }\end{array}$ & $\begin{array}{l}\text { Total } \\
\text { amino sugars } \\
(\mu \mathrm{g} . / \text { bone })\end{array}$ & $\begin{array}{l}\text { Glucos- } \\
\text { amine } \\
\text { ( } \mu \mathrm{g} \cdot / \text { bone) }\end{array}$ & $\begin{array}{l}\text { Galactos- } \\
\text { amine } \\
\text { ( } \mu \mathrm{g} . / \text { bone })\end{array}$ \\
\hline $\begin{array}{l}\text { Vitamin A explants } \\
\text { Control explants }\end{array}$ & $\begin{array}{l}1 \cdot 89 \\
4 \cdot 21\end{array}$ & $\begin{array}{l}0.21 \\
0.41\end{array}$ & $\begin{array}{l}360 \\
570\end{array}$ & $\begin{array}{r}8 \cdot 19 \\
16 \cdot 92\end{array}$ & $\begin{array}{l}1 \cdot 94 \\
2 \cdot 92\end{array}$ & $\begin{array}{l}6 \cdot 25 \\
14 \cdot 0\end{array}$ \\
\hline
\end{tabular}

Table 2. Nucleic acid content of cultured limb-bone rudiments

Results are the means of three experiments. In each experiment analyses were made of material from 12 bones.

$\begin{array}{lccc} & \text { DNA P } & \text { RNA P } & \text { RNA P/ } \\ & (\mu \mathrm{g} . / \text { bone }) & (\mu \mathrm{g} . / \text { bone }) & \text { DNA P } \\ \text { Vitamin A explants } & 0 \cdot 60 & 0 \cdot 69 & 1 \cdot 15 \\ \text { Control explants } & 0 \cdot 76 & 1 \cdot 83 & 2 \cdot 41\end{array}$

Table 3. Aerobic metabolism of cultured limb-bone rudiments

Results are the means of three experiments. In each experiment analyses of the suspending fluid were made after 90 min. incubation in Warburg flasks at $37^{\circ}$. Gas phase, air; medium, Krebs-Ringer phosphate containing $10 \%$ of neutralized horse serum. Glucose concentration, $1.8 \mathrm{mg} . / \mathrm{ml}$.

\begin{tabular}{|c|c|c|c|c|c|c|}
\hline & \multicolumn{2}{|c|}{ Uptake of $\mathrm{O}_{2}$} & \multicolumn{2}{|c|}{ Production of lactic acid } & \multicolumn{2}{|c|}{ Utilization of glucose } \\
\hline & $\mu \mathrm{l} . / \mathrm{hr} . /$ bone & $\begin{array}{l}\mu \mathrm{l} . / \mathrm{hr} . / \mu \mathrm{g} . \\
\text { of DNA P }\end{array}$ & $\mu \mathrm{g} . / \mathrm{hr} . / \mathrm{bone}$ & $\begin{array}{l}\mu \mathrm{g} . / \mathrm{hr} . / \mu \mathrm{g} . \\
\text { of } \mathrm{DNA} \mathrm{P}\end{array}$ & $\begin{array}{c}\mu \mathrm{g} . / \mathrm{hr} . / \\
\text { bone }\end{array}$ & $\begin{array}{l}\mu \mathrm{g} . / \mathrm{hr} . / \mu \mathrm{g} . \\
\text { of DNA P }\end{array}$ \\
\hline $\begin{array}{l}\text { Vitamin A explants } \\
\text { Control explants }\end{array}$ & $\begin{array}{l}1.00 \\
1.72\end{array}$ & $\begin{array}{l}1 \cdot 76 \\
2 \cdot 38\end{array}$ & $\begin{array}{l}16 \cdot 5 \\
13 \cdot 2\end{array}$ & $\begin{array}{l}27 \cdot 6 \\
17 \cdot 4\end{array}$ & $\begin{array}{l}24 \\
46\end{array}$ & $\begin{array}{l}37 \\
58\end{array}$ \\
\hline
\end{tabular}


cludes their use as a basis for expressing the metabolism of the rudiments. We have adopted two criteria : the DNA phosphorus to give a measure of the metabolism on a 'cellular' basis and the metabolism of the whole rudiment without taking into account any changes in composition. The oxygen uptake of the rudiments grown in the presence of the vitamin and expressed on either basis was depressed, but the rate of lactic acid formation was increased. Glucose utilization was less in the vitamin A-treated material than in the controls (Table 3).

Clot lysis. The bone rudiments are cultivated on a plasma : embryo extract clot and are transferred to fresh medium at 2-day intervals; during each $48 \mathrm{hr}$. period the explants become surrounded by a zone of lysis, which is very much larger in the vitamin A-treated cultures than in the controls. In an attempt to measure this lytic effect we estimated the amount of acid-soluble and acidinsoluble nitrogen in the medium at the end of the experiment. After 6 days' cultivation the percentage of acid-soluble nitrogen in the control cultures was $2 \cdot 25$ and in the vitamin A-treated cultures $\mathbf{5 \cdot 4 0}$. It is known that the fibrin of plasma clots may contain adsorbed fibrinolysin (Bidwell, 1953) and it was possible that the action of the vitamin was to activate this enzyme. To test this possibility, culture dishes containing vitamin $\mathbf{A}$ or control medium without explants were prepared and incubated for 2 days; there was no apparent lysis and no difference in the ratio of acid-soluble to acid-insoluble nitrogen between the vitamin $A$ clots and the controls.

\section{DISCUSSION}

Although the wet and dry weights of the vitamin A-treated explants are only $\mathbf{5 0} \%$ of the control values (Table 1), the DNA content, which may be taken as an approximate measure of cell number, is $80 \%$ of the controls (Table 2). This suggests that the severe inhibition of growth in length and weight is mainly due to a substantial reduction in the amount of intercellular material rather than in number of cells, an interpretation that is supported by the histological finding (Fell \& Mellanby, 1952) that in the vitamin A-treated cartilage the intercellular partitions become narrow and lose their metachromasia. The histological changes in the matrix are probably correlated with the low amino sugar content of the vitamin A-treated cartilage as compared with that of the controls (Table 1).

Fell et al. (1956) have shown that the synthesis of new cartilage matrix is inhibited by excess of vitamin A. They suggested that, under the influence of excess of vitamin $\mathbf{A}$, the cartilage cells may produce an enzyme which results in the liberation of sulphated mucopolysaccharide, and hence in the dissolution of existing matrix. That hydrolytic enzyme activity might be concerned in the changes produced in cartilage matrix under the influence of excess of vitamin $\mathbf{A}$ was further indicated by the similarity between the effects on the intercellular material of the vitamin and of papain protease; this was true whether the comparison were made on the cartilage of young rabbits in vivo (Thomas et al. 1960) or on limb-bone rudiments in organ culture (Fell \& Thomas, 1960). As a tentative working hypothesis, Fell \& Thomas (1960) suggested that "vitamin A may enhance the activity of a number of cellular enzymes, one of which resembles papain in its effect; such an enhanced hydrolytic activity might be due to the activation of enzymes, to their greater production or to their increased liberation through an increased permeability of the cells or their organelles'.

Experiments which will be reported in the following paper (Lucy, Dingle \& Fell, 1961) have shown that the cells of normal embryonic cartilage in fact contain a hydrolase which under appropriate conditions can remove from the matrix most of the amino sugars and the capacity for metachromatic staining. Another paper (Dingle, 1961) suggests that the vitamin acts by releasing enzymes from the lysosomes.

\section{SUMMARY}

1. After 6 days' cultivation in medium containing added vitamin A (10 i.u./ml.) the wet and dry weights and amino sugar content of cartilaginous limb-bone (chick) rudiments were half those of controls on normal medium.

2. Compared with the control cultures, the amount of deoxyribonucleic acid was $80 \%$ and the amount of ribonucleic acid was $40 \%$.

3. The vitamin depressed the rate of oxygen uptake but increased that of lactic acid formation.

4. There was twice as much acid-soluble nitrogen in the used culture medium (plasma-embryo extract clot) of the vitamin A-treated explants as in that of the control, indicating a greater proteolytic activity in the presence of the vitamin.

One of us (J.T.D.) is in receipt of a grant from the British Empire Cancer Campaign. We are much indebted to Mr L. J. King for his assistance in the organ-culture work, and to Miss P. Carter and Mr R. J. Thomson for their help in the biochemical estimations.

\section{REFERENCES}

Barker, J. B. \& Summerson, N. H. (1941). J. biol. Chem. 138, 535.

Bidwell, E. (1953). Biochem. J. 55, 497.

Boas, N. F. (1953). J. biol. Chem. 204, 553. 
Burton, K. (1956). Biochem. J. 62, 315.

Dingle, J. T. (1961). Biochem. J. 79, 509.

Fell, H. B. \& Mellanby, E. (1952). J. Physiol. 116, 320.

Fell, H. B., Mellanby, E. \& Pelc, S. R. (1956). J. Physiol. $134,179$.

Fell, H. B. \& Thomas, L. C. (1960). J. exp. Med. 111, 719.

Friend, D. G. \& Hastings, A. B. (1940). Proc. Soc. exp. Biol., N.Y., 45, 137.

Gardell, S. (1953). Acta chem. scand. 7, 207.

Hawk, P. B., Oser, B. L. \& Summerson, W. H. (1952). Practical Physiological Chemistry, p. 820. London: J. and A. Churchill Ltd.
Kent, P. \& Whitehouse, M. W. (1955). Biochemistry of the Aminosugars. London: Butterworths Scientific Publications.

Lucy, J. A., Dingle, J. T. \& Fell, H. B. (1961). Biochem. J. 79, 500 .

Nelson, N. (1944). J. biol. Chem. 153, 375.

Rondle, C. J. M. \& Morgan, W. T. J. (1955). Biochem. J. 61, 586.

Thomas, L., McCluskey, R. T., Potter, J. L. \& Weissmann, G. (1960). J. exp. Med. 111, 705.

Umbreit, W. W., Burris, R. H. \& Stauffer, J. F. (1957). Manometric Techniques. Minneapolis: Burgess Publishing Co.

Biochem. J. (1961) 78, 500

\title{
Studies on the Mode of Action of Excess of Vitamin A
}

\author{
2. A POSSIBLE ROLE OF INTRACELLULAR PROTEASES \\ IN THE DEGRADATION OF CARTILAGE MATRIX
}

\author{
By J. A. LUCY, J. T. DINGLE AND HONOR B. FELL* \\ Strangeways Research Laboratory, Cambridge
}

(Received 8 September 1960)

When cartilaginous limb-bone rudiments from 6 to 7-day chick embryos are cultivated in vitro, the cartilage differentiates into a hypertrophic region, proliferative zones of flattened cells and epiphyses as in normal development. If excess of vitamin $A$ is added to the culture medium, the cartilage differentiates at approximately the normal rate but the metachromatic staining properties of the matrix are greatly reduced (Fell \& Mellanby, 1952). A similar loss of metachromasia occurs when papain is added to the culture medium (Fell \& Thomas, 1960). The injection of papain into rabbits results in a collapse of the ears, accompanied by disappearance of metachromasia from the matrix of the ear cartilage (Thomas, 1956). Similar injections can also cause total disappearance throughout the body of the metachromatic staining properties of cartilage matrix (Spicer \& Bryant, 1958; McCluskey \& Thomas, 1958) and the appearance in blood and urine of a mucopolysaccharide that resembles chondroitin sulphates A and C (Bryant, Leder \& Stetten, 1958). A depletion of the chondromucoprotein of cartilage and decrease of ${ }^{35} \mathrm{~S}$ content of cartilage matrix have been observed (Tsaltas, 1958) in rabbits which have received sodium [ ${ }^{35}$ S] $]$ sulphate and papain; later an increased quantity of ${ }^{35} \mathrm{~S}$ in serum and urine and of glucuronic acid in urine occur. The administration of large amounts of vitamin A to rabbits causes histological changes in cartilage that are remark-

* Foulerton Research Fellow, Royal Society. ably similar to those seen in animals treated with small amounts of papain (Thomas, McCluskey, Potter \& Weissmann, 1960).

These observations suggest that some of the effect of vitamin A on the cartilage of embryonicchick rudiments may be mediated through the action of a proteolytic enzyme system present in the cartilage, which degrades the structural components of the matrix with a resultant loss of polysaccharide. In the preceding paper it is reported that, when grown in vitro in the presence of excess of vitamin A, the cartilaginous limb-bone rudiments from 6- to 7-day chick embryos have a greater proteolytic effect on the medium than control explants in normal medium (Dingle, Lucy \& Fell, 1961). A possible interpretation of this is that the activity of proteolytic enzymes in the tissue is enhanced by vitamin A. In this paper evidence is reported that an enzyme system which will degrade cartilage matrix is present in bone rudiments from normal chick embryos. The enzyme, or group of enzymes, is active after hypoosmotic treatment of the tissues; the optimum $\mathrm{pH}$ of the system is in the acid region.

\section{MATERIALS AND METHODS}

Material. All experiments were performed on limb-bone rudiments from 8-9-day chick embryos. At this stage the limb bones consist of a cartilaginous rod differentiated into the usual three zones of epiphyses, flattened (proliferative) cells and hypertrophic cells; the hypertrophic zone is 